Jurnal Qua Teknika, Vol. 8 No. 2 September 2018

p-ISSN: 2088-2424; e-ISSN: 2527-3892

Fakultas Teknik Universitas Islam Balitar, Blitar

Http://qua.unisbablitar.ejournal.web.id; Email; quateknika@Gmail.com

Achendri M. Kurniawan, Devita Sulistiana. 2018. Pengaruh Penambahan Abu Cangkang Bekicot Pada

Semen Ramah Lingkungan Terhadap Kuat Tekan Mortar.

Jurnal Qua Teknika, (2018), 8(2) : 63-69

\title{
PENGARUH PENAMBAHAN ABU CANGKANG BEKICOT PADA SEMEN RAMAH LINGKUNGAN TERHADAP KUAT TEKAN MORTAR
}

\author{
Achendri M. Kurniawan'), Devita Sulistiana ${ }^{2)}$ \\ ${ }^{1}$ Fakultas Teknik, Universitas Islam Balitar \\ jl. Majapahit no. 4 Blitar \\ email: achendri.ac@gmail.com \\ ${ }^{2}$ Fakultas Keguruan dan Ilmu Pendidikan, Universitas Islam Balitar \\ jl. Majapahit no. 4 Blitar \\ email: devitasulistiana17@gmail.com
}

\begin{abstract}
ABSTRAK
Blitar Regency is one of the strange culinary centers, among which are processed various foods from snail base ingredients, ranging from kripik, sate oseng-oseng and so on as well as the existence of Blitar district is one of the rice barns in East Java. With the existence of Blitar district as a snail-based culinary producer and one of the rice barns in East Java, this is not spared from several problems, such as the disposal of snail shells in the river and burning of rice straw in rice fields which both will cause environmental damage. This study aims to examine the use of snail shell ash and rice straw ash as a substitute material for cement in mortar mixtures against mortar compressive strength. The research method used was the experimental method by mixing fine aggregate main ingredients with snail shell ash and rice straw ash then testing the compressive strength. The results of the compressive test with the addition of the percentage of snail shell shell turned out to increase by $54.78 \%$.
\end{abstract}

Kata kunci: Abu Bekicot, Abu Jerami Padi, Kuat Tekan Mortar,

\section{PENDAHULUAN}

Kabupaten Blitar merupakan salah satu lumbung padi di wilayah Jawa Timur sehinggan keberadaan jerami padi yang melimpah masih tidak termanfaatkan dengan baik. Diantara sekian banyak kegunaan jerami padi, sebagian besarnya dimanfaatkan untuk keperluan-keperluan tradisional seperti perapian, abu gosok, pembakaran batu-bata, campuran batu-bata dan sebagainya. Dibandingkan dengan potensinya, jelas pemanfaatan abu jerami ini tampak monoton dan juga bernilai guna rendah. Bagi industri semen di tanah air, bahan baku semen yang digunakan berupa batu kapur, tanah liat, pasir silika, pasir besi dan fly ash yang berasal dari abu sisa pembakaran batubara. Abu terbang ( Fly Ash ) ini tidak mempunyai kemampuan mengikat seperti halnya semen. Tetapi dengan kehadiran air dan ukuran partikelnya yang halus, oksida silika yang dikandung oleh abu terbang akan bereaksi secara kimia dengan kalsium hidroksida yang terbentuk melalui proses hidrasi semen dan menghasilkan zat yang dapat mengikat. Fly ash dapat diganti dengan bahan-bahan yang lain yang mempunyai kandungan silika oksida tinggi seperti abu jerami padi.

Tanaman padi memiliki batang yang beruas-ruas. Panjang batang tergantung pada jenisnya. Pada jenis unggul biasanya berbatang pendek atau lebih pendek daripada jenis lokal, sedangkan jenis padi yang tumbuh di tanah rawa dapat lebih panjang lagi, yaitu antara 1-2 meter. Biasanya setelah panen hasil, batang padi tidak dipergunakan lagi dan dibuang begitu saja sehingga menjadi kumpulan jerami padi yang tidak berguna lagi. Jerami tersebut kebanyakan terdiri dari batang padi, tetapi ada juga terdapat ujung daunnya.

Setelah padi dipanen, bulir padi atau gabah dipisahkan dari jerami padi. Perbandingannya yang dapat diperoleh antara gabah dan jerami tergantung dari varietas padi biasanya adalah 1: 1 atau 1:1.25.

Jerami adalah tanaman padi yang telah diambil bulirnya (gabahnya) sehingga tinggal batang dan daunnya yang merupakan limbah pertanian terbesar. Jerami sebagai limbah pertanian sering menjadi permasalahan bagi petani sehingga sering dibakar untuk mengatasi masalah tersebut. Di beberapa daerah di Indonesia, jerami diangkut seluruhnya untuk pakan ternak, pembuatan kertas dan lain-lain (Mediastika, 2007).

Jerami padi terdiri atas daun, pelepah daun, dan ruas atau buku. Ketiga unsur ini relatif kuat karena mengandung silika, dan selulosa yang tinggi dan pelapukannya memerlukan waktu yang lama. Namun, apabila jerami padi diberi perlakuan tertentu akan mempercepat terjadinya perubahan strukturnya (Kohar dan Setyaningrum, 2007). Kandungan dari Jerami Padi ialah lignoselulosa yang terdiri dari tiga komponen fraksi serat yaitu selulosa $32,1 \%$, hemiselulosa $24 \%$, dan lignin $18 \%$. Disamping itu juga jerami padi mengandung 
Jurnal Qua Teknika, Vol. 8 No. 2 September 2018

p-ISSN: 2088-2424; e-ISSN: 2527-3892

Fakultas Teknik Universitas Islam Balitar, Blitar

Http://qua.unisbablitar.ejournal.web.id; Email; quateknika@Gmail.com

Achendri M. Kurniawan, Devita Sulistiana. 2018. Pengaruh Penambahan Abu Cangkang Bekicot Pada

Semen Ramah Lingkungan Terhadap Kuat Tekan Mortar.

Jurnal Qua Teknika, (2018), 8(2) : 63-69

silika (Howard,2003). Menurut Reddy dan Yang (2006) bahwa komposisi dari jerami padi terdiri dari 40\% selulosa, $30 \%$ hemiselulosa, $15 \%$ silika dan $15 \%$ lignin.

Jerami adalah hasil samping usaha pertanian berupa tangkai dan batang tanaman serealiayang telah kering, setelah biji-bijiannya dipisahkan. Massa jerami kurang lebih setara dengan massa biji-bijian yang dipanen. Jerami memiliki banyak fungsi, di antaranya sebagai bahan bakar, pakanternak, alas atau lantai kandang, pengemas bahan pertanian (misal telur), bahan bangunan(atap, dinding, lantai), mulsa, dan kerajinan tangan. Jerami umumnya dikumpulkan dalam bentuk gulungan, diikat, maupun ditekan. Mesin balerdapat membentuk jerami menjadi gulungan maupun kotak

Jerami merupakan limbah pertanian terbesar serta belum sepenuhnya dimanfaatkan karena adanya faktor teknis dan ekonomis. Pada sebagian petani, jerami sering digunakan sebagai mulsa pada saat menanam palawija. Hanya sebagian kecil petani menggunakan jerami sebagai pakan ternak alternatif di kala musim kering karena sulitnya mendapatkan hijauan. Di lain pihak jerami sebagai limbah pertanian,sering menjadi permasalahan bagi petani, sehingga sering di bakar untuk mengatasi masalah tersebut. Menurut Badan Pusat Statistik, produksi padi nasional mencapai 71,29 juta ton pertahun pada tahun 2011. Sedangkan produksi jerami padi dapat mencapai $12-15$ ton per hektar per panen, bervariasi tergantung pada lokasi dan jenis varietas tanaman padi yang digunakan (Berita Resmi Statistik, 2013).

Berdasarkan data Badan Pusat Statistik (2014), produksi padi di Indonesia pada tahun 2014 sebesar 70,83 juta ton gabah kering giling (GKG), sedangkan produksi jerami padi yang dihasilkan dapat mencapai $50 \%$ dari produksi gabah kering panen atau sekitar 35,46 juta ton.Namun demikian, pemanfaatan jerami padi oleh para petani pada umumnya masih rendah.

Kabupaten Blitar juga daerah penghasil daging bekicot yang merupakan salah satu hasil komoditi favorit. Hal ini dapat di buktikannya dengan adanya kampung kuliner bekicot di wilayah siraman Kabupaten Blitar. Di daerah tersebut pemanfaatan daging bekicot sebagai bahan makanan antara lain oseng-oseng bekicot, sate bekicot, dan kripik bekicot. Selama ini pemanfaatan cangkang bekicot belum maksimal pengelolaannya hanya terbatas sebagai bahan baku pakan ternak sebagian sedikit dan mayoritas di buang ke suangai. Hal ii menjadikan pencemaran lingkungan semakin hari semakin meningkat terutama pendangkalan sungai. Pada kenyataanya kulit bekicot mengandung senyawa kapur $\mathrm{CaO}$ dengan persentasenya yaitu 66,70\%. Senyawa $\mathrm{CaO}$ merupakan salah satu senyawa kimia utama penyusun semen.

Penelitian lain oleh Rahmadsyah Yazid Putra1 dan Nursyamsi, diketahui bahwa pemakaian abu cangkang bekicot sebagai bahan substitusi semen cenderung bersifat sebagai bahan retarder dalam campuran pasta semen, sedangkan abu cangkang kelapa sawit cenderung bersifat sebagai accelerator dalam campuran pasta semen. Nilai slump campuran beton menurun dengan meningkatnya persentase substitusi abu cangkang bekicot, sebaliknya dengan meningkatnya persentase substitusi abu cangkang kelapa sawit maka nilai slump campuran beton naik.

Penelitian serupa dilakukan oleh Frieska Ariesta S dan Dyah Sawitri, diperoleh hasil bahwa abu sampah organik mengandung 69,7\% $\mathrm{CaCO} 3 ; 12,1 \% \mathrm{KCl} ; 4 \% \mathrm{Cd} 0.15 \mathrm{Gd} 0.85 ; 3 \% \mathrm{SiO} 2 ; 8,1 \% \mathrm{Fe}$ ( $\mathrm{Se} 0.5 \mathrm{Te} 0.5$ ) dan $3 \%$ Al2ErGe2, Abu cangkang bekicot mengandung $100 \% \mathrm{CaCO}$. Ditentukan tiga variasi jumlah komposisi Abu sampah:Abu cangkang bekicot yaitu Ekosemen A (58,2\%:40\%); Ekosemen B (49,1\%:49,1\%) dan Ekosemen C (54,01\%:44,09\%). Sebagai variabel kontrol digunakan Semen Portland jenis OPC (Ordinary Portland Cement) merek 'Semen Gresik'. Dari hasil pengujian fisika didapat ekosemen B paling mendekati nilai 'Semen Gresik' OPC yaitu kuat tekan 3 hari $(7,2 \mathrm{~kg} / \mathrm{cm} 2)$ dan densitas serbuk $(2,535 \mathrm{gr} / \mathrm{ml})$.

Bekicot dikategorikan sebagai binatang malam karena lebih aktif bergerak di malam hari sedangkan pada siang hari bekicot beristirahat atau tidur. Bekicot termasuk binatang lunak (mollusca) dan diklasifikasikan ke dalam kelas.

Gastropoda (Santoso, 1989). Bekicot banyak dimanfaatkan untuk makanan manusia sebagai sumber protein (dikenal sebagai escargot ) di Eropa, Asia dan Afrika karena mengandung banyak daging dan mengandung banyak asam amino esensial. Bekicot juga sudah menjadi komoditas ekspor. Ekspor bekicot ke Perancis pada tahun 1986 baru mencapai 1.212 ton, sedangkan pada tahun 1990 naik menjadi 11.000 ton (Koswara, 2002).

Besarnya manfaat dan pertumbuhan perdagangan ini menyebabkan timbulnya limbah cangkang bekicot dalam jumlah yang cukup besar. Limbah cangkang bekicot banyak ditemukan di kabupaten Kediri. Cangkang bekicot banyak mengandung senyawa-senyawa antara lain protein, lemak, air, kitin dan mineral-mineral seperti kalsium, kalium, magnesium, besi, seng dan mangan (Aboua, F., 1990). Kandungan nutrisi bekicot adalah sebagai berikut: 
Jurnal Qua Teknika, Vol. 8 No. 2 September 2018

p-ISSN: 2088-2424; e-ISSN: 2527-3892

Fakultas Teknik Universitas Islam Balitar, Blitar

Http://qua.unisbablitar.ejournal.web.id; Email; quateknika@Gmail.com

Achendri M. Kurniawan, Devita Sulistiana. 2018. Pengaruh Penambahan Abu Cangkang Bekicot Pada Semen Ramah Lingkungan Terhadap Kuat Tekan Mortar.

Jurnal Qua Teknika, (2018), 8(2) : 63-69

Tabel 1. Kandungan Nutrisi Bekicot

\begin{tabular}{lll}
\hline No & Nutrisi & Jumlah \\
\hline 1 & Protein kasar & $51,8 \%$ \\
2 & Lemak kasar & $13,61 \%$ \\
3 & Serat kasar & $6,09 \%$ \\
4 & Kadar abu & $24 \%$ \\
5 & Energi metabolis & $2094,98 \mathrm{Kal} / \mathrm{kg}$ \\
\hline
\end{tabular}

Tarigan (2008:14)

Hewan berlendir ini telah lama dilirik orang untuk dikonsumsi karena memiliki kadungan gizi dan nutrisi yang tinggi. Berdasarkan penelitian Creswell dan Kopiang pada 1981, daging bekicot mengandung asam amino dan protein tinggi. Cangkangnya juga kaya kalsium. Secara detail, protein yang terkandung sekitar $12 \mathrm{gram} /$ 100 gram, lemak 1\%, hidrat arang $2 \%$, kalsium $237 \mathrm{mg}$, fosfor $78 \mathrm{mg}$, Fe 1,7 mg, serta vitamin B komplek (terutama B12).

\section{Abu Cangkang Bekicot}

Abu cangkang bekicot diperoleh dari proses pembakaran cangkang bekicot hingga menjadi abu atau dimasukkan ke dalam oven dengan suhu tertentu. Setelah itu cangkang bekicot dengan sendirinya akan menjadi halus.

Tabel 2 Komposisi Abu Cangkang Bekicot

\begin{tabular}{ll}
\hline Komponen & Kadar $(\%$ berat $)$ \\
\hline $\mathrm{CaO}$ & 66,70 \\
$\mathrm{SiO} 2$ & 7.88 \\
$\mathrm{Fe} 2 \mathrm{O} 3$ & 0.03 \\
$\mathrm{MgO}$ & 22.28 \\
$\mathrm{~A} 12 \mathrm{O} 3$ & 1.25 \\
\hline
\end{tabular}

Sumber: Siregar, S.M. 2009

\section{METODE PENELITIAN}

\section{Tempat dan Waktu Penelitian}

Dikarenakan pemenuhan sarana dan prasarana yang menunjang penelitian, sehingga penelitian ini dilaksanakan di berbagai tempat terpisah, seperti pada Tabel berikut:

Tabel 3 Tempat dan Waktu Penelitian

\begin{tabular}{|c|c|c|c|}
\hline No. & Tempat penelitian & Waktu & Kegiatan penelitian \\
\hline 1 & $\begin{array}{l}\text { Puskesmas kepanjenkidul Kota } \\
\text { Blitar }\end{array}$ & $24-25$ Mei 2018 & $\begin{array}{l}\text { pembakaran bahan baku } \\
\text { cangkang bekicot dan jerami } \\
\text { padi }\end{array}$ \\
\hline \multirow[t]{2}{*}{2} & $\begin{array}{l}\text { Laboratorium teknik sipil } \\
\text { Universitas Islam Balitar }\end{array}$ & $1 \quad-4$ Juni 2018 & $\begin{array}{l}\text { - Penghalusan bahan baku } \\
\text { semen }\end{array}$ \\
\hline & & 1 September 2018 & $\begin{array}{l}\text { - Pembuatan dan } \\
\text { pencetakan mortar }\end{array}$ \\
\hline 3 & $\begin{array}{l}\text { Laboratorium teknik sipil, Univ } \\
\text { Brawijaya Malang }\end{array}$ & 19 September 2018 & Uji tekan kualitas semen \\
\hline
\end{tabular}


Jurnal Qua Teknika, Vol. 8 No. 2 September 2018

p-ISSN: 2088-2424; e-ISSN: 2527-3892

Fakultas Teknik Universitas Islam Balitar, Blitar

Http://qua.unisbablitar.ejournal.web.id; Email; quateknika@Gmail.com

Achendri M. Kurniawan, Devita Sulistiana. 2018. Pengaruh Penambahan Abu Cangkang Bekicot Pada Semen Ramah Lingkungan Terhadap Kuat Tekan Mortar.

Jurnal Qua Teknika, (2018), 8(2) : 63-69

\section{Bahan dan Alat}

Bahan

Bahan utama yang digunakan dalam penelitian ini adalah cangkang bekicot dan jerami padi. Cangkang bekicot diperoleh dari limbah indsutri pengolahan daging bekicot yang berada di Desa Siraman, Kec. Selopuro, Kabupataen Blitar. Sedangkan jerami padi diperoleh dari area persawahan di Desa Langon, Kec. Ponggok, Kab. Blitar. Bahan lainnya adalah pasir besi yang diperoleh dari pantai pasur, Desa Bululawang, Kecamatan Bakung, Blitar, Jawa Timur, dan tanah liat yang diperoleh dari gunung Pegat, Kec. Srengat, Kab. Blitar.

Alat

Alat yang digunakan dalam penelitian ini meliputi:

Tabel 4 Alat yang Dipergunakan Dalam Penelitian

\begin{tabular}{|c|c|c|c|}
\hline No. & Penggunaan & Jenis alat & $\begin{array}{l}\text { Kapasitas/ } \\
\text { kuantitas }\end{array}$ \\
\hline 1 & $\begin{array}{l}\text { Pembakaran cangkang bekicot dan } \\
\text { jerami padi }\end{array}$ & $\begin{array}{ll}\text { - } & \text { Incenerator } \\
\text { - } & \text { Drum dari bahan besi }\end{array}$ & $100 \mathrm{Kg} / 1$ \\
\hline 2 & Penghalusan bahan baku & $\begin{array}{l}\text { Blender merk Sharp SB TI } \\
181 \mathrm{P}\end{array}$ & $2 \mathrm{~L} / 1$ \\
\hline 3 & Penimbangan bahan & $\begin{array}{l}\text { - Timbangan analitik item } \\
\text { AR } 2140 \text { Ohaus Corp. Pine } \\
\text { Brook NJ USA } \\
\text { - Cawan petri } \\
\text { - Sendok bahan }\end{array}$ & 500 gram $/ 1$ \\
\hline 4 & $\begin{array}{l}\text { Pembakaran bahan baku semen (abu } \\
\text { cangkang bekicot, AJP, psir besi, dan } \\
\text { tanah liat) }\end{array}$ & Furnace FB 1410 & Suhu $1000^{\circ} \mathrm{C} / 1$ \\
\hline 5 & $\begin{array}{l}\text { Analisis bahan kimia dalam abu } \\
\text { cangkang bekicot dan AJP } \\
\text { Analisis bahan kimia semen }\end{array}$ & $\begin{array}{l}\text { Difraksi sinar X (XRD) merk } \\
\text { X',Pert PRO }\end{array}$ & 1 \\
\hline 6 & Pembuatan dan pencetakan mortar & $\begin{array}{ll}\text { - } & \text { Timbangan digital } \\
\text { - } & \text { Gelas ukur } \\
\text { - } & \text { Baskom } \\
\text { - } & \text { Pengaduk } \\
\text { - } & \text { Alat cetak (kubus } \\
& \text { berukuran } 2,5 \times 2,5 \mathrm{~cm} 2 \text { ) } \\
& \text { dari bahan besi. }\end{array}$ & $\begin{array}{l}1 \\
1 \\
2 \\
1 \\
9\end{array}$ \\
\hline 7 & Analisis kuat tekan mortar & loadcel proving ring & $\begin{array}{l}\text { kapasitas tekan } \\
\text { beban minimal } 0,5 \\
\text { Kg. }\end{array}$ \\
\hline
\end{tabular}

\section{Tahapan Penelitian}

1. Abu jerami padi didapatkan dengan cara membakar jerami padi di dalam alat insinerator pada suhu $800^{\circ} \mathrm{C}$.

2. Abu bekicot didapatkan dengan cara pemanasan dalam furnace dari cangkang bekicot yang telah ditumbuk halus pada alu besi. Suhu yang digunakan untuk pemanasan hingga menjadi abu bekicot adalah $700^{\circ} \mathrm{C}$. Setelah diperoleh abu bekicot dilakukan penumbukan hingga menjadi serbuk yang lebih halus dengan menggunakan mortar dan diayak menggunakan saringan.

3. Tanah liat yang masih berbentuk bongkahan dihancurkan dengan menggunakan alu besi, kemudian dihaluskan dengan meggunakan blender dry mill. 
Jurnal Qua Teknika, Vol. 8 No. 2 September 2018

p-ISSN: 2088-2424; e-ISSN: 2527-3892

Fakultas Teknik Universitas Islam Balitar, Blitar

Http://qua.unisbablitar.ejournal.web.id; Email; quateknika@Gmail.com

Achendri M. Kurniawan, Devita Sulistiana. 2018. Pengaruh Penambahan Abu Cangkang Bekicot Pada Semen Ramah Lingkungan Terhadap Kuat Tekan Mortar.

Jurnal Qua Teknika, (2018), 8(2) : 63-69

4. Pasir besi dihaluskan dengan cara digerus dengan menggunakan mortar.

5. Seluruh bahan pembuat semen dicampur dengan beberapa variasi komposisi yang telah ditentukan. Pencampuran seluruh bahan menggunakan dry ball mill kecepatan $56 \mathrm{rpm}$.

6. Setelah dilakukan pencampuran bahan, selanjutnya dilakukan pembakaran pada suhu $800^{\circ} \mathrm{C}$ menggunakan alat insinerator.

7. Kemudian ekosemen dihaluskan kembali dengan menggunakan mortar, setelah itu diayak dengan saringan no.200 (0,0075 mm).

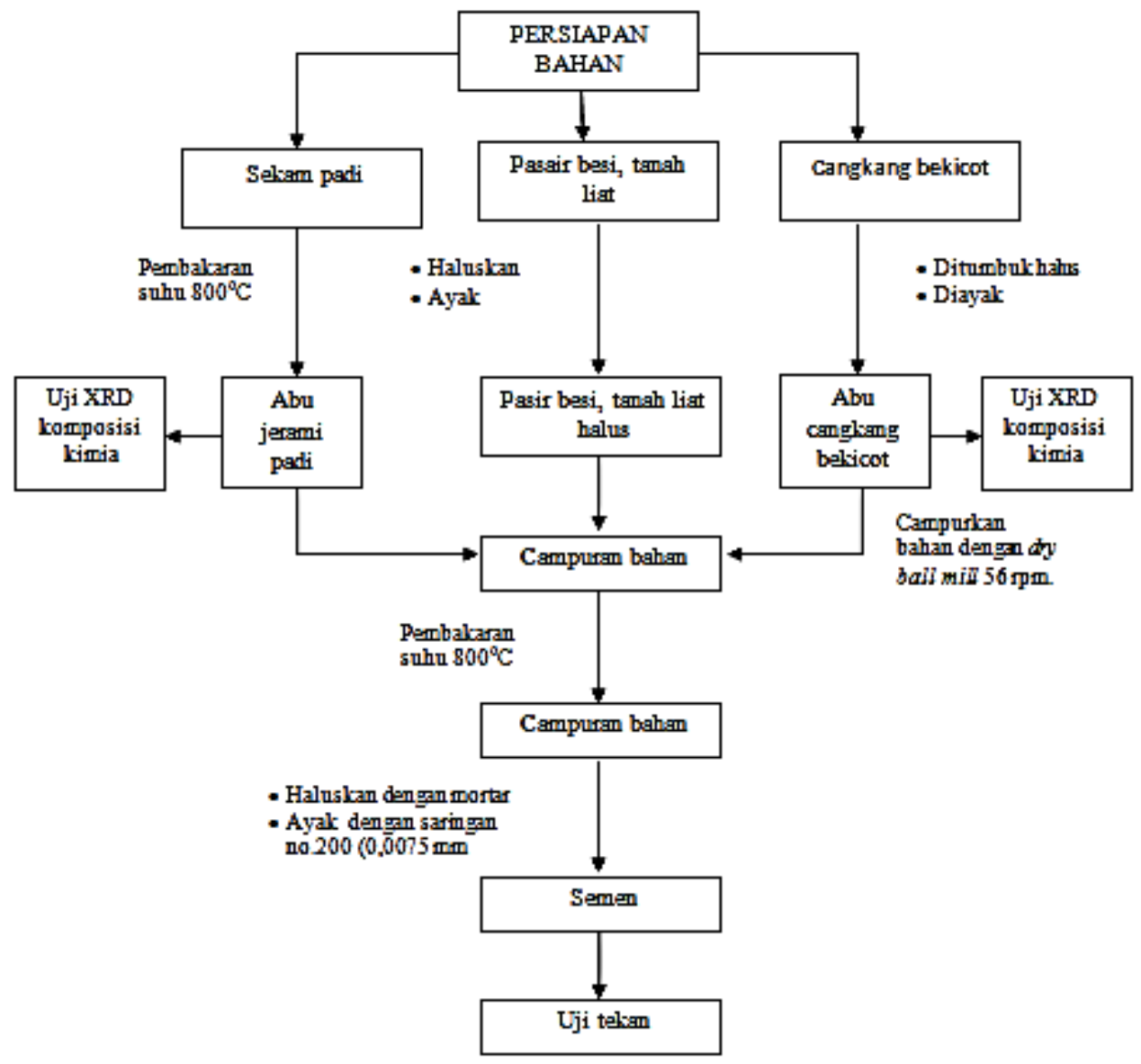

Gambar 1. Prosedur Kerja

\section{Analisis Data}

Analisis terhadap kandungan/komposisi kimia bahan baku semen dari abu jerami padi dan abu cangkang bekicot dilakukan dengan menggunakan difraksi sinar X. Sementara uji terhadap kuat tekan mortar dilakukan melalui metode SNI 15-2049-2004 dengan persamaan:

$$
\mathrm{P}=\frac{\mathrm{Fm}}{\mathrm{A}}
$$

Dimana:

$\mathrm{P} \quad=$ Kuat tekan $(\mathrm{Mpa})$

$\mathrm{F}_{\mathrm{m}} \quad$ = Gaya tekan maksimum $(\mathrm{N})$

A = Luas Penampang benda uji $\left(\mathrm{mm}^{2}\right)$

\section{HASIL DAN PEMBAHASAN}

Ekosemen dihasilkan dengan mencampurkan abu jerami padi (AJP), abu cangkang bekicot, pasir besi, dan tanah liat dengan 3 variasi perbandingan. 
Jurnal Qua Teknika, Vol. 8 No. 2 September 2018

p-ISSN: 2088-2424; e-ISSN: 2527-3892

Fakultas Teknik Universitas Islam Balitar, Blitar

Http://qua.unisbablitar.ejournal.web.id; Email; quateknika@Gmail.com

Achendri M. Kurniawan, Devita Sulistiana. 2018. Pengaruh Penambahan Abu Cangkang Bekicot Pada Semen Ramah Lingkungan Terhadap Kuat Tekan Mortar.

Jurnal Qua Teknika, (2018), 8(2) : 63-69

Tabel 5. Variasi Campuran Bahan Baku Ekosemen Tipe A, B, dan C

\begin{tabular}{llll}
\hline Bahan Campuran & Ekosemen A $(\mathrm{g})$ & Ekosemen B $(\mathrm{g})$ & Ekosemen C $(\mathrm{g})$ \\
\hline Abu cangkang bekicot & 58,19 & 49,17 & 54,18 \\
AJP & 40,19 & 49,19 & 44,20 \\
Pasir besi & 0,32 & 0,34 & 0,34 \\
Tanah liat & 1,31 & 1,33 & 1,31 \\
\hline
\end{tabular}

Ekosemen dengan campuran abu cangkang bekicot dan abu jerami padi yang dihasilkan selanjutnya akan dibuat beton/mortar dengan campuran pasir dan katalis air dengan perbandingan tertentu (Tabel 5) dicetak dalam cetakan kubus berukuran 25 x 25 x $25 \mathrm{~mm}$. Mortar selanjutnya didiamkan selama 28 hari. Untuk mengetahui kualitas semen yang dihasilkan digunakan uji tekan dengan menggunakan loadcel proving ring dengan kapasitas tekan beban minimal 0,5 Kg di Laboratorium Teknik Sipil, Universitas Brawijaya Malang.

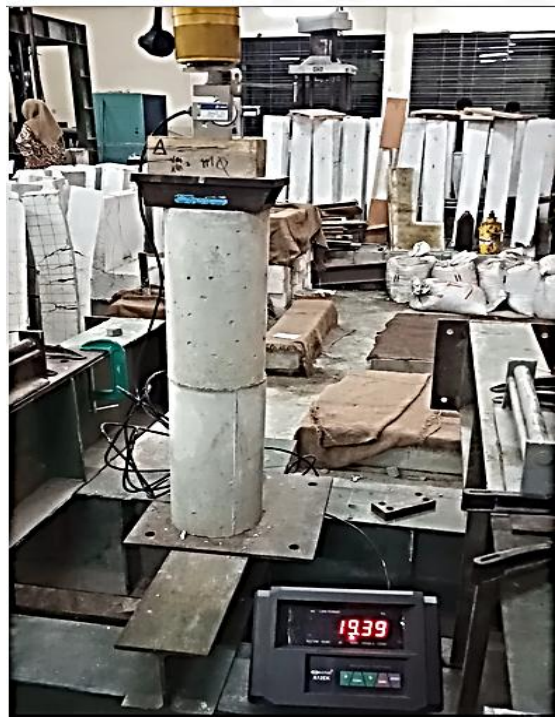

Gambar 2. Uji Kuat Tekan Mortar untuk Menguji Kualitas Ekosemen

Tabel 6 Hasil Uji Kuat Tekan Mortar Waktu Simpan 28 Hari

\begin{tabular}{|c|l|l|l|}
\hline Satuan & A & B & C \\
\hline F $(\mathrm{Kg})$ & 18,06 & 6,19 & 9,88 \\
\hline $\mathrm{A}(\mathrm{cm} 2)$ & 2,27 & 2,27 & 2,27 \\
\hline $\mathrm{P}(\mathrm{Kg} / \mathrm{cm} 2)$ & 7,94 & 2,73 & 4,35 \\
\hline
\end{tabular}

Berdasarkan data uji tekan terhadap mortar waktu simpan 28 maksimum, diksetahui bahwa ekosemen tipe A memiliki daya uji terbesar, yaitu 7,94 Kg/cm2. Ekosemen tipe A ini dihasilkan dari campuran 58,19 gram abu cangkang bekicot dan 40,19 gram abu jerami padi. Jumlah abu cangkang bekicot yang digunakan merupakan jumlah yang terbesar jika dinbandingkan ekosemen B, maupun C. Sehingga dapat disimpulkan bahwa dengan penambahan abu cangkang bekicot maka kualitas ekosemen semakin baik.

Nilai kuat tekan mortal ini masih jauh jika dibandingkan dengan kuat tekan semen gresik OPC, yaitu 171 $\mathrm{Kg} / \mathrm{cm}^{2}$. Hal ini dikarenakan senyawa utama dalam semen, yaitu trikalsium silikat $\left(\mathrm{C}_{3} \mathrm{~S}\right)$. Kuantitas senyawa yang terbentuk selama proses pengikatan berlangsung mempengaruhi kekuatan beton dan umur awal pada 14 hari pertama. Senyawa $\mathrm{C}_{3} \mathrm{~S}$ akan terbentuk pada kalsinasi dan sintering pada suhu. Kalsinasi adalah proses pelepasan senyawa $\mathrm{CO}_{2}$ ke udara dan penguraian secara maksimum unsur-unsur reakti yang terkandung dalam material semen. Proses ini terjadi hingga suhu $1200^{\circ} \mathrm{C}$. Sintering adalah proses peleburan semua material dan reaksi maksimum antara $\mathrm{CaO}$ dengan $\mathrm{SiO}_{2}, \mathrm{Al}_{2} \mathrm{O}_{3}$, dan $\mathrm{Fe}_{2} \mathrm{O}_{3}$. Mineral ini membentuk senyawa utama semen, yaitu $\mathrm{C}_{3} \mathrm{~S}$ (Alite), $\mathrm{C}_{2} \mathrm{~S}$ (Belite), $\mathrm{C}_{3} \mathrm{~A}$ (Celite), dan $\mathrm{C}_{4} \mathrm{AF}$ (Felit). Proses ini terjadi hingga suhu $1500^{\circ} \mathrm{C}$. Dalam penelitian ini, pemanasan bahan baku ekosemen hanya pada suhu $800^{\circ} \mathrm{C}$, sehingga yang terjadi hanya proses 
Jurnal Qua Teknika, Vol. 8 No. 2 September 2018

p-ISSN: 2088-2424; e-ISSN: 2527-3892

Fakultas Teknik Universitas Islam Balitar, Blitar

Http://qua.unisbablitar.ejournal.web.id; Email; quateknika@Gmail.com

Achendri M. Kurniawan, Devita Sulistiana. 2018. Pengaruh Penambahan Abu Cangkang Bekicot Pada

Semen Ramah Lingkungan Terhadap Kuat Tekan Mortar.

Jurnal Qua Teknika, (2018), 8(2) : 63-69

kalisinansi, sementara proses sintering belum bisa terjadi. Senyawa $C_{3} A$ dan $C_{4} A F$ akan terbentuk pada sintering dengan suhu di atas $1000^{\circ} \mathrm{C}$. Dalam proses ini, silikon dan besi akan mengalami peleburan. Titik lebur dari silikon adalah $1414^{\circ} \mathrm{C}$ dan besi $1535^{\circ} \mathrm{C}$..

\section{SIMPULAN}

Dalam penelitian tersebut dapat di simpulkan sebagai berikut:

1. Uji kuat tekan pada mortar ekosemen yang dihasilkan diketahui bahwa semen tipe A yang terdapat penambahan abu cangkang bekicot lebih bersar menghasilkan kuat tekan meningkat sebesar 54,78\%.

Dalam penelitian tersebut dapat diberikan saran sebagai berikut:

1. Proses pengeringan bahan eko semen harus benar-benar kering sebelum di lakukan penghalusan, hal ini di karenakan akan mempengaruhi kualitas ekosemen pada saat pelaksanaan furnace karena bahan ekosemen masih memiliki kandugan air.

2. Proses pemanasan terhadap bakan baku ekosemen sebaiknya perlu ditingkatkan lagi suhunya, sehingga proses sintering bisa terjadi dan dapat menghasilkan senyawa utama penyusun semen.

3. Perlu dilakukan penelitian lebih lanjut untuk mengetahui kualitas semen yang dihasilkan, tidak terbatas pada uji kuat tekan saja.

4. Proses pencetakan mortar harus dilakukan pemadatan yang merata sehingga saat pengujian tekannya tidak terdapat bagian yang keropos yang dapat mengurangi kualitas kuat tekannya.

5. Alat cetak morta sebaikknya silinder dan sudah ada pembuka cetakan sehingga akan mempermudah pelebasan benda uji dari alat cetak.

6. Perataan permukaan benda uji merupakan proses perataan pembebanan, sehingga pembebanan pada benda uji dapat di salurkan secara merata ke seluruh bagian benda uji.

7. Proses perawatan benda uji harus di perhatikan juga terutama terkait perendaman setelah pelepasan benda uji dari cetakanya

8. Untuk mengetahui daya tahan semen terhadap pengaruh lingkungan, perlu uji lanjutan dengan merendam mortar dengan menggunakan larutan kapur jenuh.

\section{REFERENSI}

Ariesta, F.S \& Sawitri, D. 2013. Studi Eksperimental Pembuatan Ekosemen dari Abu Sampah dan Cangkang Bekicot sebagai Bahan Alternatif Pengganti Semen. Jurnal Teknik Kimia POMITS ITS Surabaya. Nomor 2, Vol. 2, Hal. 1-5.

Metungku NA, dkk. 2017. Pemurnian dan Karakterisasi Senyawa $\mathrm{SiO}_{2}$ Berbasis Pasir Kuarsa Dari Desa Pendolo Kecamatan Pamona Selatan Kabupaten Poso. Jurnal Gravitasi, Jurusan Fisika FMIPA Universitas Tadulako Palu. Nomor 1, Vol. 16. Hal. 39-43.

Departemen P.U. 2002. RSNI S-05-2002 (Spesifikasi Beton Serat dan Beton Semprot), LPMB, Bandung.

Malasyi, Syibral, Welsi, \& Fardansyah. 2014. Analisis Pengaruh Penggunaan Abu Jerami Terhadap Kuat Tekan Beton. Teras Jurnal, Vol.4, No.2. Universitas Malikussaleh.

Pratama, R.S. Pengaruh Pasir Pantai Sebagai Agregat Halus dan Cangkang Kerang Sebagai Substitusi Parsial Semen Terhadap Kuat Tekan Beton. 2017. Skripsi. Jember: Universitas Jember.

Pratiwi, N.G.Pembuatan Ekosemen Berbahan Baku Abu Cangkang Kerang, Abu Sampah Organik, Dan Lumpur Limbah. 2016. Skripsi. Surabaya: Universitas Airlangga

Sriyadi, Eko. 2010. Analisis Kuat Tekan dan Kuat Tarik Belah Beton Dengan Bahan Tambah Abu Sekam Padi dan Bestmittel. Skripsi. Surakarta. Universitas Muhammadiyah Surakarta.

Sunardi, dkk. 2013. Pemanfaatan Cangkang Bekicot (Achatina Fulica) Sebagai Katalis untuk Reaksi Transesterifikasi. Jurnal Fisika FLUX, FMIPA UNLAM Banjarbaru. Nomor 2, Vol. 10, Hal. 100109.

Qoniah I, dkk. 2011. Penggunaan Cangkang Bekicot Sebagai Katalis untuk Reaksi Transesterifikasi Refined Palm Oil. Prosiding Skripsi Jurusan Kimia. FMIP ITS Surabaya. 